lecturer at Imperial College. His original investigations on adsorption and on emulsions and other colloid topics form notable contributions to our knowledge of physical chemistry. After a brief statement regarding the establishment of the Faraday lectureship, the president (Prof. F. C. Donnan) introduced Dr. Irving Langmuir, who then delivered the seventeenth Faraday Lecture entitled "Monolayers on Solids". At the conclusion of the lecture he presented the Faraday Medal to Dr. Langmuir.

\section{Life-size Model of a Blue Whale}

A MODEL of a 93-ft. Blue whale has just been completed in the Whale Hall of the British Museum (Natural History). It is constructed of plaster of Paris and cement on a wood and wire-netting framework and weighs between six and seven tons. The proportions and colour are based on photographs and written descriptions and on very numerous measurements of actual specimens. Features of interest in the model are: the great size of the head, which is nearly a fifth of the total body length ; the eye just behind the angle of the mouth, and the very small ear opening a little distance behind the eye; the tapering beautifully stream-lined flippers, and the enormous tail flukes some eighteen feet from tip to tip. The numerous grooves covering the throat and chest are a typical feature of the family Balænopteridæ to which this species belongs. The Blue whale, which grows to $100 \mathrm{ft}$., is the largest of all living animals and, so far as is known, the largest that has ever existed. At birth it is more than $24 \mathrm{ft}$. in length, and by its third year of life when it becomes sexually mature it is 74-77 ft. long. Its distribution is world wide, but at the present time the only remaining important area of concentration is in the Antarctic. There it is being hunted by the whalers for the oil obtained from blubber and flesh. During the 1936-37 antarctic whaling season, out of a total of 32,821 whales slaughtered, 14,183 were Blue whales.

\section{A Kentish Iron Age Hill-Fort}

THE hill-fort at Oldbury, near Ightham, Kent, the excavation of which was described by Mr. J. B. Ward before the Society of Antiquaries of London on December 15, is the largest hill-fort of iron age date in Britain. Its ramparts are some two miles in circumference and enclose a space of 120 acres. Originally, it would appear from the evidence of sections cut in the ramparts, the erection was a place of refuge rather than a permanent settlement. "This was at the very beginning of the first century A.D. ; but later the gate facing the North Downs was elaborately refortified with stone-revetted fighting platform and outworks. The associated pottery shows that this refortification was carried out in A.D. 43 at the time of the Claudian invasion. Although Oldbury lay off the line of march of the Claudian armies proceeding from East Kent, where they landed, to Colchester, the evidence of the burning of the gates and quantities of sling stones suggest that it was sacked then or soon after. The camp was not again occupied. No Belgic pottery was found in the original fortification, but only in the later works.
From this Mr. Ward infers that the original fortifications were erected by another people who had established themselves in the Wealden areas of Kent, Surrey and Sussex, working the local supplies of iron, and that its original purpose must have been to serve as a protection against the inroads of the Belgic tribes, whose headquarters lay north of the Thames. The occurrence of Belgic pottery in the later fortifications suggests that by that time the Belgic people had taken possession of the fort.

\section{Mesolithic Dwellings at Farnham, Surrey}

ExHIBIrs illustrating the culture of the inhabitants of mesolithic pit-dwellings at Farnham, Surrey, are now on view in the Prehistoric Galleries of the British Museum (Bloomsbury). These dwellings, on a site which is the only one of its kind as yet found in Britain, have been excavated by Dr. and Mrs. Grahame Clark. The results of the excavation, which has occupied two seasons, were described by Dr. Clark at a recent meeting of the Prehistoric Society. The site of the settlement, which is the property of the Farnham Urban District Council, consists of a number of irregularly shaped pits, three feet deep in places, which have been scraped out of the gravel of the old Blackwater River. These pits represent the chief habitations of a mesolithic people, who probably spent their summers hunting on the Lower Greensand, when they lived in temporary shelters. Four huts have been excavated. In one pit there was a hearth and near another there were signs of a post, which probably had supported some light framework arranged tent-wise. Generally, however, the roofing seems to have been of the nature of a lean-to. Large numbers of microlithic implements were discovered, with flint axes, scrapers and waste flint cores and flakes. Altogether, between forty and fifty thousand worked flints have been discovered, and fifteen thousand flints cracked by fire have been found. These houses are, as stated, the first of their kind to be found in Britain; and they probably represent the first type of habitation in use in Britain other than the cave. They are considered to date from about 3000 B.c., and support the contention that artificially constructed dwellings are more ancient than has been thought. On the Continent, evidence is accumulating that mesolithic man was nomadic, inhabiting light shelters in the summer, and more or less permanent dwellings, usually of the pitdwelling type, in the winter. The exhibits now shown in the British Museum are drawn from two of the dwellings excavated, and include a large and representative selection of the implements found.

\section{Accessions to the British Museum (Bloomsbury)}

INTERESTING additions to the collections of British antiquities of the British Museum (Bloomsbury) were announced at the December meeting of the Trustees. Among these the most important is an iron sword of the second century B.c., with its bronze scabbard mount, which has been lent for temporary exhibition by the Duke of Northumberland. It was found in the River Witham below Lincoln in 1826, probably at the same time as the famous bronze shield of the 
iron age, which, with its characteristic Celtic ornament combining the use of metal and enamel, has long been one of the Museum's most striking exhibits among British antiquities. The decoration of the seabbard mount is an example of the earliest Celtic art of Britain, and shows the La Tène curvilinear style of ornamentation in the form in which it reached Britain. Other accessions, also of great interest, come from a round barrow at Riffley Wood, near King's Lynn, which has been exeavated by Mr. I. J. Thatcher and Mr. P. L. K. Sebwabe. Among these are a segmented bead and a ring pendant of bluish-green faience, which were associated with nine or ten cremated urn burials of the Middle Bronze Age found on top of the mound. They belong to a class of ornament which has been found in bronze age burials in Britain and on the Continent ; and they agree in all respects with examples found at Tell el-Amama in Egypt, dating from about 1400 B.c. The grave pit of the mound below the level at which the urn burials were found, contained no remains; but the whole of the surface-level below the barrow was covered with pottery fragments, representing hundreds of vessels. These sherds were of beaker pottery of the Early Bronze Age, of the approximate dating of 1800 B.c. It seems clear that this was not a habitation site, and the sherds are thought to be either the debris of the floor of the dead man's hut, which was brought here entire, or, perhaps more probably, the result of a ritual, which involved the scattering of a large number of potsherds.

\section{The Iron Industry in South Yorkshire}

BEFORE the introduction of mild steel about sixty years ago, engineers had to rely on wrought iron made by the puddling process introduced by Henry Cort in 1783. Among the various brands of wrought iron none was superior to those made in Yorkshire. But long before Cort's time iron was made in Yorkshire, and in a paper entitled "The South Yorkshire Iron Industry 1698-1759", read to the Newcomen Society on December 14, Dr. A. Raistrick gave an account of the operations carried out in the SheffieldLeeds-Huddersfield area about two hundred years ago. The source of his information was manuscripts discovered a few years ago, and now preserved by the Bradford City Museums and Library Committee, relating to the activities of the various branches of the Spencer family, all Quakers. The documents give accounts of 10 furmaces, 14 forges and 5 slitting mills, and though much of the information relates to the business side of the industry, they embody a considerable amount of technical information about the mining of the iron ore, the construction and working of the furnaces and forges and the production of charcoal. The main group of furnaces was on the outcrop of the Tankersley Ironstone and near streams which were used for driving water-wheels for working the bellows. As in Sussex, a determining factor of the industry was the supply of charcoal, and it was rarely possible for a furnace to be worked for more than half the year. The manuscripts, as Dr. Raistrick said, put a new complexion on the story of the iron industry in the area.

\section{British Coal Utilisation Research Association}

ON December 14, the British Coal Utilisation Research Association held its first ordinary general meeting under the presidency of Sir Evan Williams. It was founded in April last, having incorporated the Research Department of the Combustion Appliance Makers Association (Solid Fuel) and with a membership covering all sections of the industries of coal and its appliance manufacturers. Its income from these sources and Government grant is guaranteed at $£ 29,000$ for five years. Premises near West Brompton Station have been secured and are being adapted to the purposes of an experimental station. It was stated that fruitful work has already been done in both the domestic and the industrial sections. In the former this has been concerned with the open fire, and the use of natural smokeless fuels and smoke reduction. In this connexion it is claimed that success has been achieved in the design of solid fuel cookers to replace in railway restaurant cars those fired with oil gas. On the industrial side, the supply and use of solid fuel for small industry, pulverized fuel, and industrial temperature measurement have engaged attention. A special committee has been set up to study the question of producer gas transport and supplement the work already in progress at the Fuel Research Station. It has long been a matter of reproach against the coal industry that it has shown complete indifference to the rational and efficient utilization of its commercial product. The launching of this Association will remove this reproach, and, as the president said, it will be "the missing member of a team which will work in harmony to bring about a more perfect knowledge of the properties of coal measures and advances in their fuller and better utilization".

\section{Blind Landing System for Royal Air Force Equipment}

THE Air Ministry has announced its intention to equip all R.A.F. bombers and reconnaissance aircraft with the Lorenz blind approach system. If experiments during this winter prove this to be successful, the fighter class of aircraft will then also be so equipped. This follows the announcement that forty R.A.F. aerodromes would have the radio transmitting apparatus for this system installed, as mentioned in NATURE of November 26. The apparatus to be carried in each machine weighs $50 \mathrm{lb}$. and costs about $£ 200$. Its manipulation demands a certain technique, and pilots need considerable practice before being able to use it in addition to the other movements and observations that are incidental to the operation of landing a modern high-speed aeroplane. A special 'Link' trainer is used for practice in the use of the Lorenz system, upon which approaches and landings can be simulated without leaving the ground. These are to be provided at R.A.F. flying schools, in addition to which each service station will carry one. The training of the personnel will be undertaken by special instructors, who will have already attended courses at the Central Flying School at Upavon, Wilts. 